\title{
Bacterial etiologic agents of urinary tract infection in children in the Islamic Republic of Iran
}

Shahab Modarres' and Navideh Nassiri Oskoil ${ }^{2}$

$$
\begin{aligned}
& \text { الملبيات المخرثومية لعدوى المسالك البولية بين الأطفال في جمهورية إيران الإسلامية }
\end{aligned}
$$

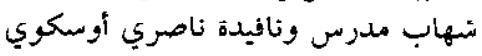

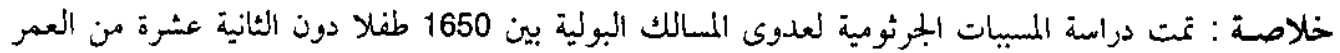

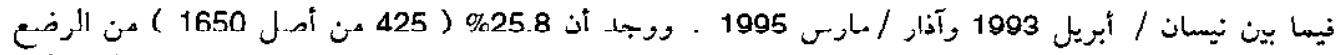

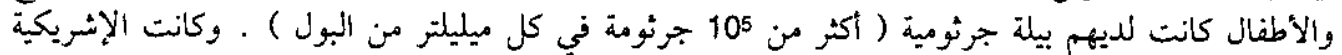

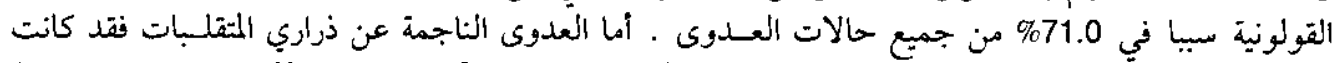

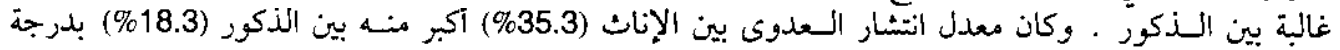

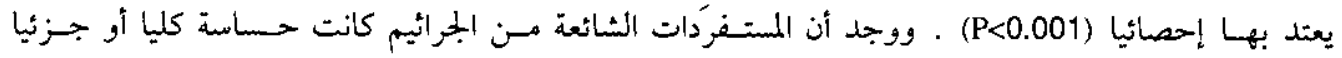

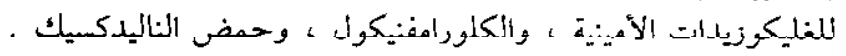

ABSTRACT The bacterial agents of urinary tract infections were studied in 1650 children under 12 years of age between April 1993 and March 1995. It was found that 25.8\% (425/1650) of infants and children showed bacteriuria ( $>10^{5}$ bacteria per millilitre of urine). Escherichia coli was responsible for $71.0 \%$ of all infections. Infections caused by Proteus spp. were predominantly found in boys. Girls showed a higher prevalence of infection (35.3\%) than boys (18.3\%), which was statistically highly significant $(P<0.001)$. The most commonly isolated bacteria were partially or totally sensitive to the aminoglycosides, chloramphenicol and nalidixic acid.

Les agents étiologiques bactériens des infections des voles urlnalres chez les enfants en République islamique d'Iran

RESUME Les agents bactériens des infections des voies urinaires ont été étudiés chez 1650 enfants de moins de 12 ans entre avril 1993 et mars 1995 . On a trouvó que $25,8 \%$ des nourrissons et des enfants (425/1650) présentaient une bactériurie $>10^{5}$ bactéries par millilitre d'urine). Escherichia coli était à l'origine de $71 \%$ de toutes les infections. Les infections causées par Proteus spp. ont été détectées principalement chez les garçons. Une prévalence plus élevée de l'infection a été observée chez les filles $(35,3 \%)$ que chez les garçons ( $18,3 \%)$, ce qui est très significatif statistiquement $(\mathrm{P}<0,001)$. Les bactéries isolées le plus couramment étaient soit partiellement soit totalement sensibles aux aminosides, au chloramphénicol et à l'acide nalidixique.

${ }^{4}$ Pasteur Institute of the Islamic Republic of Iran, Teheran.

${ }^{2}$ Shahid Beheshti University of Medical Sciences. Teheran. Islamic Republic of Iran.

Received: 31/10/95; accepted: 04/01/96

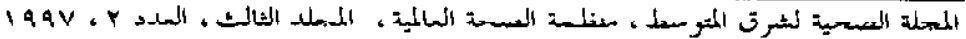




\section{Introduction}

Urinary tract infections (UTIs) represent the commonest genitourinary disease in children, and are the second commonest infection which affects them [I]. Urinary tract infections in children are particularly important because their occurrence may be associated with sume congenital abnormality of the urinary tract or an error in management. If not corrected, these may lead to recurrent infections causing damage to the urinary tract $[1,2]$.

Infection may occur at many places along the genitourinary tract: urethra, bladder, ureter, renal pelvis, or renal parenchyma $[1,3]$. The prevalence of urinary tract infection varies markedly with sex and age. Symptomatic urinary tract infections occur in about 1.4 per 1000 newborn infants, with a slight male preponderance [3]. It is assumed that the short urethra in girls predisposes them to ascending infection, because, for example Escherichia coli serotypes from bowel flora are the same as those that infect the urinary tract. However, factors other than the proximity of gut flora to the short urethra are likely because the female to male ratio in urinary tract infection varies directly with age $[I, 4]$.

Microbiologically, urinary tract infection exists when pathogenic microorganisms are detected in the urinary tract $[5,6]$. The infection is considered significant and requires treatment when more than $10^{5} \mathrm{mi}-$ croorganisms per millilitre of urine are present in a properly collected specimen $[5,6]$. Gram-negative bacteria such as E. coli, Proteus spp., Klebsiella spp., Enterobacter spp., Serratia spp. and Pseudomonas spp. are usually detected in recurrent infections, especially in association with stones, obstruction, urologic manipulation and nosocomial catheter-associated infections $[2,5,7]$. Microbial sensitivity tests should be done first in order to direct therapy of the urinary tract infection [8].

The aim of the study was to identify the bacterial agents of urinary tract infection in children under 12 years of age and to study their sensitivity and resistance to antibiotics.

\section{Subjects and methods}

\section{Subjects}

Urinary specimens were collected from 1650 children under 12 years of age suffering from urinary tract infections, who were either inpatients or outpatients at three medical centres in Teheran between April 1993 and March 1995. While some patients had symptoms of dysuria, frequency, urgency, burning, flank pain, suprapubic pain, fever and haematuria, most patients were asymptomatic. Of the 1650 children, $40 \%$ were males and $60 \%$ were females.

\section{Laboratory techniques}

The specimens were collected in sterile tubes by standard methods available and transported to the laboratory for examination. Urine specimens that were not examined within six hours of collection were stored at $+4{ }^{\circ} \mathrm{C}$, because at $0-4{ }^{\circ} \mathrm{C}$ the bacterial count will remain unchanged for 24 48 hours [9].

Examination of urine for cells. About $5 \mathrm{ml}$ of urine was centrifuged, the supernatants uipped off and the deposit resuspended in the urine that drained back (about $0.1 \mathrm{ml}$ ). A wet film of the suspension was examined microscopically with the $\times 40$ and the $\times 100$ objectives. More than two or three white cells per field with the $\times 100$ objective were regarded as abnormal. The presence of any red cells was regarded as abnormal [9].

Culture. For bacteriological examination, the following media were inoculated: Mc- 
Conkey's agar, blood agar, nutrient agar and heart infusion broth. Additional selective media for some bacteria were inoculated as designed by the participating laboratory. In general, urine was cultured onto a $5 \%$ sheep blood agar and McConkey's agar. The plates were streaked with a measured drop of urine transversely across the media. All sample plates were incubated for 48 hours at $37^{\circ} \mathrm{C}$ in $5 \%-10 \% \mathrm{CO}_{2}$, to lower the oxidation-reduction potential for anaerobic growth. Bacterial identification was done by examination of the overnight culture with a hand lens and also by a standard biochemical and sensitivity test to antibiotics using a disk diffusion method (Kirby-Bauer) [9].

Bacterial counts. A standard loop method for bacterial colony counts of urine specimens was used. An anichrome loop with an internal diameter of $3 \mathrm{~mm}$, delivery approximately $0.006 \mathrm{ml}$, was used for inoculation of the samples in the standard loop technique. In this method, an inoculating loop of standard dimensions is used to take up a small, approximately fixed and known volume of uncentrifuged urine and spread it over a plate of agar culture medium. The plate is incubated at 37 " $\mathrm{C}$ for 24 hours, the number of colonies is counted or estimaled, and this number is used to calculate the number of viable bacteria per millilitre of urine [9].

\section{Results}

Of a total of 1650 urine specimens from infants and children investigated for bacterial etiologic agents in Teheran, bacteriuria $\left(>10^{5}\right.$ bacteria per millilitre of urine) was found in $25.8 \%$ of patients. The most common bacterial agent of urinary infections was $E$. coli $(71.0 \%$ of total isolates in both sexes). Proteus spp. as identified as the causative organism in $24.8 \%$ of isolates in boys against $2.8 \%$ in girls, which was statistically significant $(P<0.001)$. Other etiologic bacteria among all isolates, in order of frequency were: Klebsiella spp. (10.5\%), Enterobacter spp. (3.7\%), Pseudomonas aeruginosa $(3.1 \%)$, Citrobacter spp. (2.0\%) and Salmonella typhi $(0.7 \%)$ (Table 1$)$.

\begin{tabular}{lrrrrrr}
\hline $\begin{array}{l}\text { Table } 1 \text { Distribution of isolated bacteria in children with urinary tract } \\
\text { infection by sex }\end{array}$ \\
\hline Organism & \multicolumn{7}{c}{ Number and percentage of isolates } \\
\cline { 2 - 7 } & No. & $\%$ & No. & $\%$ & No. & $\%$ \\
\hline E. coli & 75 & 16.3 & 251 & 54.7 & 326 & 71.0 \\
Kiebsiella spp. & 9 & 2.0 & 39 & 8.5 & 48 & 10.5 \\
Enterobacter spp. & 5 & 1.1 & 12 & 2.6 & 17 & 3.7 \\
Prot. vulgaris & 11 & 2.4 & 2 & 0.4 & 13 & 2.8 \\
Prot. mirabilis & 22 & 4.8 & 7 & 1.5 & 29 & 6.3 \\
P. aeruginosa & 2 & 0.4 & 10 & 2.2 & 14 & 0.1 \\
S. typhi & 2 & 0.4 & 1 & 0.2 & 3 & 0.7 \\
Citrobacter spp. & 5 & 1.1 & 4 & 0.9 & 9 & 2.0 \\
Total & 133 & 29.0 & 326 & 11.0 & 459 & 100 \\
\hline
\end{tabular}


Table 2 Rate of bacterial urinary Infection by sex and age

\begin{tabular}{|c|c|c|c|c|c|c|c|}
\hline \multirow[t]{2}{*}{ Sex } & \multicolumn{6}{|c|}{ Age group (years) } & \multirow{2}{*}{ Total } \\
\hline & $0-2$ & $2-4$ & $4-6$ & $6-8$ & $8-10$ & $10-12$ & \\
\hline Male & $\begin{array}{c}20.0 \% \\
(45 / 225)\end{array}$ & $\begin{array}{c}24.2 \% \\
(32 / 132)\end{array}$ & $\begin{array}{c}13.3 \% \\
(21 / 158)\end{array}$ & $\begin{array}{c}22.6 \% \\
(31 / 137)\end{array}$ & $\begin{array}{c}15.9 \% \\
(25 / 157)\end{array}$ & $\begin{array}{c}13.6 \% \\
(16 / 118)\end{array}$ & $\begin{array}{c}18.3 \%^{\star} \\
(170 / 927)\end{array}$ \\
\hline Female & $\begin{array}{c}31.0 \% \\
(53 / 171)\end{array}$ & $\begin{array}{c}49.1 \% \\
(56 / 114)\end{array}$ & $\begin{array}{c}35.4 \% \\
(34 / 96)\end{array}$ & $\begin{array}{c}37.7 \% \\
(46 / 122)\end{array}$ & $\begin{array}{c}33.9 \% \\
(38 / 112)\end{array}$ & $\begin{array}{c}25.9 \% \\
(28 / 108)\end{array}$ & $\begin{array}{c}35.3 \%{ }^{*} \\
(255 / 723)\end{array}$ \\
\hline Total & $\begin{array}{c}24.7 \% \\
(98 / 396)\end{array}$ & $\begin{array}{c}35.8 \% \\
(88 / 246)\end{array}$ & $\begin{array}{c}21.7 \% \\
(55 / 254)\end{array}$ & $\begin{array}{c}29.7 \% \\
(77 / 259)\end{array}$ & $\begin{array}{c}23.4 \% \\
(63 / 269)\end{array}$ & $\begin{array}{c}19.5 \% \\
(44 / 226)\end{array}$ & $\begin{array}{c}25.8 \% \\
(425 / 1650)\end{array}$ \\
\hline
\end{tabular}

${ }^{*} P<0.001$

Infections were more commonly diagnosed in girls $(35.3 \%)$ than boys (18.3\%), particularly with $E$. coli, which was statistically significant $(P<0.001)$ (Tables 1 and 2 ). The data show that the majority of bacterial urinary infections were in the 24 year-old age group (35.8\%) and the lowest in the 10-12 year-old age group (19.5\%) (Table 2).

Bacterial agents isolated were most sensitive to aminoglycosides: tobramycin $(67.6 \%)$; gentamicin $(67.6 \%)$; and amikacin $(47.3 \%)$. They were $100 \%$ resistant to vancomycin, cloxacillin and amoxycillin. The lowest resistance was to nalidixic acid (4\%) (Figure 1).

\section{Discussion}

Many studies have shown the high incidence of bacterial urinary tract infection in children $[1,3]$. The results of this study show that bacteriuria was found in $25.8 \%$ of all patients, both infants and children. In addition, the commonest bacterial agents in urinary infection cases were found to be E. coli (71.0\%), Klebsiella spp. (10.5\%) and Proteus spp. (9.1\%), a result comparable to those reported by others [2].
Urinary bacterial infections are usually much more common in females $[2,10,11]$. In females, $75 \%$-90\% of all urinary infections are caused by $E$. coli, followed by Klebsiella spp. and Proteus spp. [1-3]. The present study indicates the proportions of isolates identified as $E$. coli, Klebsiella spp. and Proteus spp. infection in females arc $77.0 \%, 12.0 \%$ and $2.8 \%$, respcctively.

Some reports indicate that the incidence of Proteus spp. infection is much higher in males than in females. This may be because Proteus spp. is a more common inhabitant of the preputial sac than of the vulva, or that Proteus spp. with its active motility and swarming ability can, in comparison with other organisms, more readily traverse the longer urethra in boys $[2,10]$.

The results of this study show that a higher proportion due to Proteus spp. was cncountcred in males than females. Symptomatic and asymptomatic urinary tract infections occur in $1.2 \%-2.9 \%$ of school-aged females ald are most common $(2.5 \%)$ in the $7-11$ year-old age group [3]. The higher incidence of infection in this age group may represent the beginning of schooling when young girls face, for the first time, errors in self-management and 


\section{Resistant $\square$ Intermediate $\square$ Sensitive}

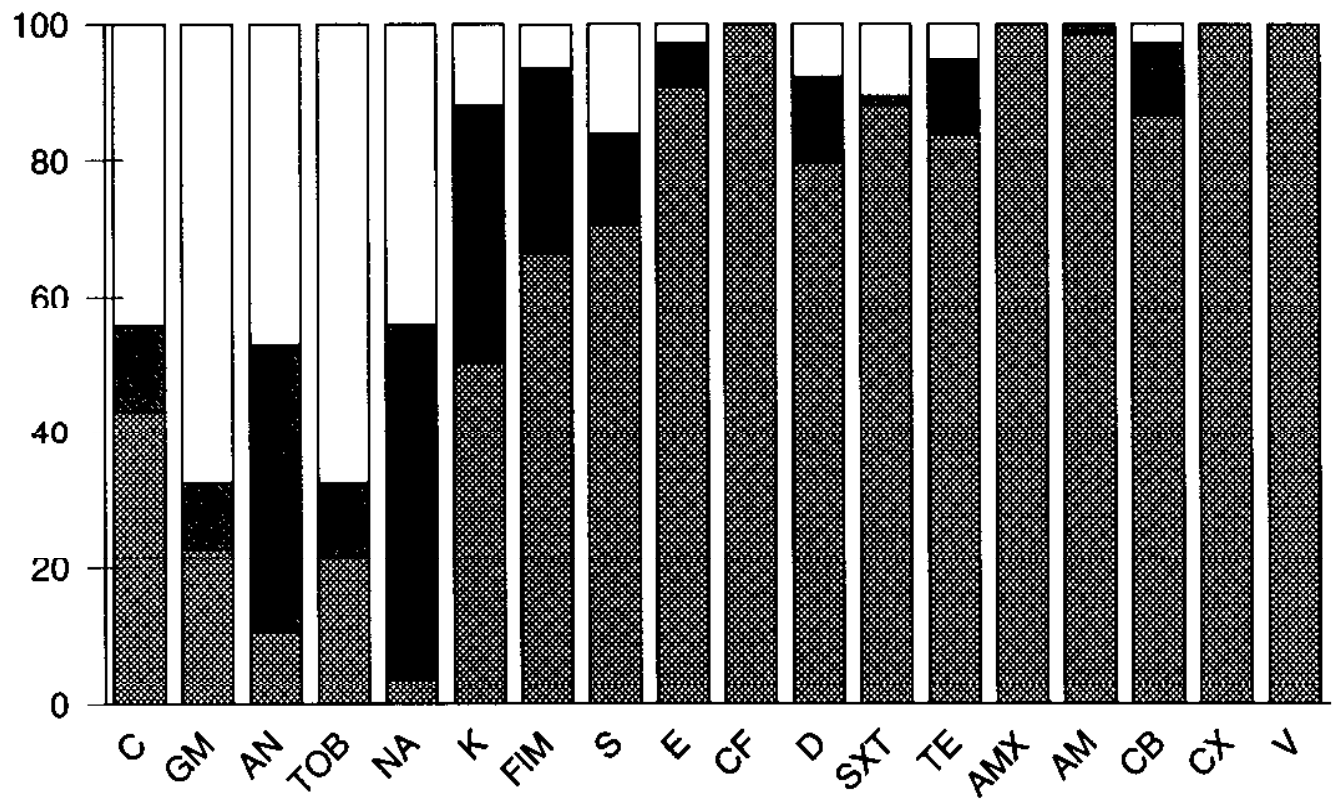

\begin{tabular}{|c|c|c|c|c|c|c|c|}
\hline $\begin{array}{l}\text { Key } \\
C \\
G M \\
A N \\
T O B\end{array}$ & $\begin{array}{l}\text { chlorampherical } \\
\text { gentamicin } \\
\text { amikacin } \\
\text { tobramycin }\end{array}$ & $\begin{array}{l}N A \\
K \\
F M \\
S \\
E\end{array}$ & $\begin{array}{l}\text { nalidixic acid } \\
\text { kanamycin } \\
\text { nitrofurantoin } \\
\text { streptomycin } \\
\text { erythromycin }\end{array}$ & $\begin{array}{l}C F \\
D \\
S X T\end{array}$ & $\begin{array}{l}\text { cephalothin } \\
\text { doxycycline } \\
\text { sulfonamides and } \\
\text { trimethoprim } \\
\text { tetracycline }\end{array}$ & $\begin{array}{l}A M X \\
A M \\
C B \\
C X \\
V\end{array}$ & $\begin{array}{l}X \text { amoxycillin } \\
\text { ampicillin } \\
\text { carbenicillin } \\
\text { cloxacillin } \\
\text { vancomycin }\end{array}$ \\
\hline
\end{tabular}

Figure 1 Sensitivity and resistance of isolated organisms to antibiotics

the embarrassment of micturating away from home. Errors in management made by schoolgirls are: to clean the perineum forwards from the anus to the vulva and to micturate infrequently. Infrequent micturition leads to overdistension of the bladder, with subsequent incomplete emptying; residual urine then interferes with bladder defences by allowing bacterial colonization of bladder urine to occur more readily. It is suggested that an important factor in the prevention of urinary tract infections in young girls is proper supervision of school lavatories [2]. The present study indicates that the prevalence rates of urinary tract infection are higher in females than males in all age groups.

In a case-controlled study, Herzog demonstrated that male infants with urinary tract infection are significantly more likely to be uncircumcised than male infants without urinary tract infection [12]. These studies suggest that uncircumcised boys are 10-39 times more likely than circumcised boys to have urinary tract infection during their first year of life $[12,13]$. 
The sensitivity/resistance ratio of bacterial etiologic agents in this study revealed that the most common bacteria of urinary tract infections were sensitive to chloramphenicol, nalidixic acid, and some aminoglycosides (tobramycin, gentamicin, amikacin), a result comparable to those reported by others $[8,14]$. However, these bacteria were resistant to vancomycin, cloxacillin, amoxycillin and cephalothin.

\section{Acknowledgements}

We would like to thank Dr M. Lessani and Dr H. Falah-Shirvani for their cooperation. We also thank members of the Department of Paediatrics of the medical centres of Loghman-Hakim, Mofid and Shoorideh for providing urinary specimens.

\section{References}

1. Feld LG, Greenfield SP, Ogra PL.Urinary tract infections in infants and children. Pediatrics review, 1989, 11(3):71-7.

2. Naylor GR. A 16-month analysis of urinary tract infection in children. Journal of medical microbiology, 1984, 17(1):31-6.

3. Behrman and Vaughan. Ne/sor texibook of pediatrics, Vol 2 Philadelphia, WB Saunders Company, 1989.

4. Jodal $U$, Winberg J. Management of children with unobstructed urinary tract infection. Pediatric nephrology, 1987, 129(1):647-56.

5. Travis LB, Bruhard $\mathrm{BH}$. Infections of the urinary tract. In; Rudolph AM et al., eds. Rudoiph's pediatrics, 19th ed. Stamford, Appleton and Lange, 1991.

6. Tolkoff NE, Rubin RH. Urinary tract infection. Significance and management. Bulletin of the New York Academy of Medicine, 1986, 62(2):131-48.

7. Warren JW. Catheter-associated urinary tract infections. Infectious disease clinics of North America, 1987. 1(4):823-54.

8. Kunin C. Use of antimicrobial agents in urinary tract infections. Advances in nephrology from the Necker Hospital, $1985,14: 39-65$.

9. Baron EJ, Finegold SM. Diagnostic microbiology. Toxtbook for the isolation and identification of pathogenic organisms, 8th ed. St. Louis, Mosby-Year Book Inc., 1990.

10. Hansson S et al. Untreated bacteriuria in asymptomatic girls with renal scarring. Pediatrioo, 1089, 84(6):964-0.

11. Ring $E$, Zobel $G$. Urinary infection and malformations of urinary tract in infancy. Archives of disease in chirahood, 1988, $63(7): 818-20$.

12. Herzog L. Urinary tract infections and circumcision. A case-control study. American journal of diseases of children, 1989 , 143(3):348-50.

13. American Academy of Pediatrics: report of the task force on circumcision. Journal of pediatrics, $1989,84(2): 388-91$.

14. Stamm WE, Turck M. Urinary tract infection and pyeionephritis. In: Braunwald E; ed Harrison's principles of internal medicine, 12th ed. New York, McGrawHill, 1991. 